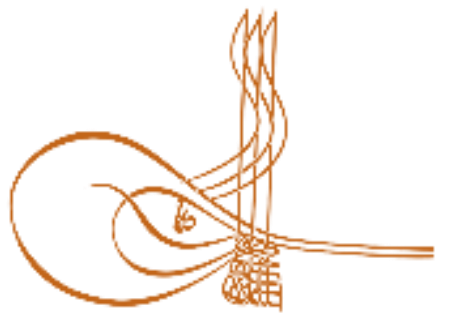

www.turkishstudies.net/turkishstudies
Turkish Studies

eISSN: $1308-2140$

Research Article / Araştırma Makalesi

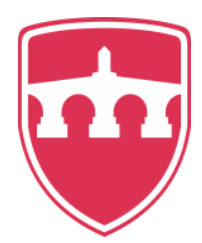

INTERNATIONAL

BALKAN

UNIVERSITY

Sponsored by IBU

\title{
Применение Ролевых Игр В Формировании Навыков Речевого Этикета Русского Языка В Коммуникативной Подготовке Студентов Специальности «Туризм» в Турции
}

\author{
The Usage Of Role-Playing Games In Speaking Etiquette Skills Development In Russian Language \\ For Communicative Preparation Of Students In The Specialty "Tourism” In Turkey
}

\author{
Maiya Myrzabekova* - Roza Umyrbekova** - Tatyana Buryachenko ${ }^{* * *}$
}

\begin{abstract}
This article is dedicated to the description of the role-playing games that permit to intensify educational process and form speaking etiquette skills in Russian as a second language, the skills that are necessary for the communication in different communicative situations. The current state of development of tourist sphere taking into account requirements of the modern market of Turkey, intercultural interaction with Russian or Russian-speaking tourists, necessity of improvement of quality of Turkish experts preparation, search of effective and intensive approaches in communicative preparation of students in teaching Russian as a second language and requirements to them confirm the relevance of the research. The research objective is the development of the role-playing games based on the modern researches in different fields of knowledge in pedagogics, culturology and management in tourism and that develop the speaking etiquette skills in everyday situations in communicative preparation of students in the specialty "tourism" in Turkey. During the study, a set of methods was applied that made it possible to fulfill the research objectives: analysis of modern concepts of an innovative approach to teaching foreign languages of a professional orientation, development of the content and application of educational and role-playing games based on modeling professional communication situations.The results of the study confirm the feasibility and effectiveness of various role-play games that improve the quality of training and interest in the study of the subject; aimed at developing the ability to determine the appropriateness of using speech etiquette formulas, navigate the flow of professional information
\end{abstract}

\footnotetext{
* Dr. Öğr. Üyesi Ankara Haci Bayram Veli Üniversitesi, Yabancı Diller Yüksekokulu, Rus dili Bölümü

Asst. Prof. Dr. Ankara Haci Bayram Veli University, Akademy of Foreing Languages, Department of Russian Language ORCID 0000-0003-2396-1042

maiya.myrzabekova@hbv.edu.tr

** Dr. Öğr. Üyesi, Al Farabi Kazak Milli Üniversitesi Filoloji Fakültesi, Temel dilbilim bölümü

Asst. Prof. Dr. Al Farabi University Faculty of Philology, Department of General Linguistics

ORCID 0000-0001-5148-2925

umyrbekova.roza68@mail.ru

**** Doç. Dr., Cusup Balasagun Kırgız Millî Üniversitesi, Rus Dili Bölümü

Asst. Prof. Dr., Kyrgyz National University named after Zhusupa Balasagyn, Inter-faculty Department of the Russian

Language

ORCID 0000-0002-3887-9554

tatyana.buryach@gmail.com
}

Cite as/ Atıf: Myrzabekova, M., Umyrbekova, R., Buryachenko, T. (2020). Применение ролевых игр в формировании навыков речевого этикета русского языка в коммуникативной подготовке студентов специальности «Туризм» в Турции, Turkish Studies, 15(2), 1167-1181. https://dx.doi.org/10.29228/TurkishStudies.41836

Received/Geliş: 18 February/Şubat 2020

Accepted/Kabul: 25 April/Nisan 2020

Copyright $\subset$ MDE, Turkey 
and learn special vocabulary and terminology, determine the communicative intentions of the dialogue partner, create the experience of public speaking, to initiate and complete a dialogue; express their communicative intent within the studied topics; master the communication strategy (it is appropriate to use speech and etiquette formulas, know the formulas of appeals, be able to express gratitude, request, consent, objection, etc.). These exercises can be used in conducting role-playing games for Russian and other languages studied as foreign languages, aimed at developing professional and communicative qualities of tourism professionals.

Structured Abstract: Introduction In the context of the globalized economy, the surge in tourism development in Turkey, with an increasing number of tourists from Russia, as well as with the toughening competition in the labor market every year, the issues of teaching Russian to students specializing in Tourism are becoming more and more relevant. A high level of speech culture and a developed economy are simply inseparable from each other. Teaching a foreign language as an integral component of professional training of specialists of any profile should be of a communicative-oriented and professional-oriented nature.

In recent years, the need to significantly improve the quality of students' formed communicative competence requires the use of interactive methods to improve the learning process. The purpose of this research is to develop the role-play games based on modern research in various fields of linguodidactics, cultural studies and tourism, aimed at developing speech etiquette skills in everyday situations for students specializing in Tourism in Turkey in solving communication problems. Today, the methodology of teaching Russian as a foreign language presents a wide variety of ways to form speech etiquette skills. These include familiarization with the main features of Russian communicative behavior, transformational, substitution, question-and-answer types of exercises, tasks with definitions, work with the source and adapted texts, analysis of the use of speech etiquette formulas in specific situations, role-play and didactic games (Berdichevsky, 2011:184).

Effectively organize professional-oriented role-play games, which can be based on simple situations: a fictional tour of historical places in Russian and Turkish cities, a tour operator's plan, a lecture or press conference of tour operators from different countries, a trip to museums, etc. For example, you can organize a role-play game "In a travel agency" (dialogue with the travel agent), when one student performs the role of the travel agent, and another of the client; "In the hotel restaurant", when one student plays the role of a visitor, and the other of the hotel waiter; "At the airport (we buy tickets)"; "At the reception desk at the hotel", etc. According to O. S. Tarasenko (2006), "such classes can be held when studying any grammar topics, to control the assimilation of lexical and grammatical material." The use of role-play games helps to create a positive education environment, to organize targeted speech practice in Russian language, its practice and intensification within its framework and skills of monologic and dialogic speech, to implement an individual approach to learning that allows to realize the principle of success for each student and increases motivation for learning of the Russian language. However, despite a fairly large number of forms, methods and techniques for teaching foreign-language students speech etiquette, they cannot be used at all stages of the language training. Most of the existing manuals on the formation of speech etiquette skills are designed for students who have an advanced level of language proficiency.

\section{Methodology}

During the study, a set of methods was applied that made it possible to fulfill the research objectives: analysis of modern concepts of an innovative approach to teaching foreign languages of a professional orientation, development of the content and application of educational and role-playing games based on modeling professional communication situations. This article presents some variants of role-play games that are included in a set of exercises for the formation of speech etiquette skills, developed for Turkish students who speak Russian from the basic to advanced level aa per RFL (Russian as a Foreign Language). For students who speak Russian at an advanced level, interactive team games such as "Hotel auction", "Travelers Club", "Expeditions", "International scientific conferences", "Tour Sales", etc. become an available type of tasks. This kind of interactive teaching methods allow students to expand their knowledge of Russia, as well as of information about cultural and historical attractions of their native land and at the same time check the level of general knowledge, erudition, logic. The topic "Travel to cities in Russia and Turkey" in the Russian language classes at the elementary level can be carried out using maps of Russia and Turkey. Students display the scheme "My way home" on maps using icons: "plane", "train", "bus", "car", "ship". They should, when necessary, calculate the travel time on all segments, taking into account stops, transfers and organize a situation that stimulates their mental activity, making them express their thoughts faster in Russian. When studying the topic

Turkish Studies, 15(2) 
"My house", "In a restaurant", "Meeting tourists", "Hotel", tasks of the reproductive nature are offered: correlation of the image with the image of these topics and a list of the following phrases: "Nice to see you!", "Welcome to the table!”, “Bon voyage!", "Welcome!”, "God bless you!”, "Happy birthday", “Good night!", "Happy New Year!", forming the ability to apply the studied formulas of speech etiquette that are most appropriate in the specific situation of this task. Discussing these illustrations, the teacher can assign roles (animate and inanimate): a hotel, a Turkish bath, a tourist from Russia, a restaurant, a guide, etc., where each participant is the bearer of a certain fictional image of the role, which he demonstrates in front of other participants and gets used to this role. For example: Good afternoon, let me introduce myself: I am a hotel. My name is Marco Polo. I have 1200 rooms. They are comfortable, bright and have sea views. I want to share with you that I do not like my Director, because he is mean. To perform "stage activities", it is necessary to create an environment of natural communication with the conditions of the educational process. (Yakup Akyel, 2013:170).

The proposed tasks include exercises of various levels of complexity: from exercises of a reproductive nature to tasks of a communicative orientation, in which the student must use the studied formulas of speech etiquette. The presence of a communicative attitude: expression of consent/disagreement, making a request or question, advice or suggestion, clarification, explanation, addition, refutation, expression of gratitude or dissatisfaction, etc. is a mandatory condition for performing exercises and developing speech (Filatcheva, 2012:15). Literature analysis shows that role-play is an education in action, which improves the quality of learning; it is a highly motivating factor, because the game arouses the interest of students, especially in terms of unpredictable outcomes; it suggests what speech models can express a particular thought in this particular situation; it is usually accompanied by excitement, which positively affects the quality of learning, increases its effectiveness (Bochkareva, 2007:155).

\section{Conclusions and suggestions}

As you know, knowledge of the Russian language is an integral part of training of the highly qualified specialists in the field of tourism and hospitality in hotels in Turkey. Organizing and conducting role-play games requires serious preparation, including the use of the hotel management system. In the classroom with a Russian language teacher, students repeat and generalize the specific features of the profession, within which the communication is held, understanding the purpose of the game and the content.

The proposed role-play games are performed by the students specializing in Tourism in the Russian language classes in order to practice speech etiquette and develop professional skills. The study revealed that role-play games should be used not only for future specialists in Tourism, but also for improving the skills of personnel in the sphere of tourism. Systematic performance of these tasks helps to achieve the main goal of teaching speech etiquette skills in the communicative training of students specializing in Tourism, that is the ability to carry out speech activities in accordance with the communication situation, using the most appropriate formulas and clichés, which will help them adapt to the Russian-speaking environment.

The results of the study confirm the feasibility and effectiveness of various role-play games that improve the quality of training and interest in the study of the subject; aimed at developing the ability to determine the appropriateness of using speech etiquette formulas, navigate the flow of professional information and learn special vocabulary and terminology, determine the communicative intentions of the dialogue partner, create the experience of public speaking, to initiate and complete a dialogue; express their communicative intent within the studied topics; adequately respond to the interlocutor's remarks, to compromise; anticipate a conflict and find ways to resolve it; formulate a problem and suggest ways to solve it; change the tactics of their behavior; master the communication strategy (it is appropriate to use speech and etiquette formulas, know the formulas of appeals, be able to express gratitude, request, consent, objection, etc.).

Keywords: Role-play games, Methods of teaching the Russian language, Pedagogy, Speech etiquette, Communication, Tourism.

Аннотация : Статья посвящена описанию ролевых игр, позволяющие интенсифицировать учебный процесс, в результате которого у студентов формируются навыки речевого этикета (русского языка как иностранного) РКИ, необходимые для общения в разных коммуникативных ситуациях. Современное состояние развития туристической сферы с учетом требований современного 
рынка Турции, межкультурное взаимодействие с русскоязычными туристами, необходимость улучшения качества подготовки турецких специалистов, поиск эффективных и инновационных подходов в коммуникативной подготовке студентов в преподавании РКИ и требования к ним подтверждают актуальность исследования. Целью исследования является разработка ролевых игр, опирающихся на современные исследования в различных областях знания педагогики, культурологии и менеджмента туризма, формирующие навыки речевого этикета в повседневных ситуациях общения, направленные на подготовку студентов специальности «Туризм» в Турции в решении коммуникативных задач. В ходе исследования был применён комплекс методов, позволивших выполнить задачи исследования: анализ современных концепций инновационного подхода к обучению иностранным языкам профессиональной направленности, разработка содержания и применения учебно-ролевых игр на основе моделирования ситуаций профессионального общения. Результаты исследования подтверждают целесообразность и эффективность применения различных ролевых игр, способствующих повышению качества обучения и интереса к изучению предмета, направленных на формирование умения определять уместность использования формул речевого этикета, ориентироваться в потоке профессиональной информации и усвоение специальной лексики и терминологии, определять коммуникативные намерения диалогического партнера, формировать опыт публичного выступления, инициировать и завершать диалог, выражать свое коммуникативное намерение в пределах изученных тем, владеть стратегией общения(уместно употреблять речевые и этикетные формулы, знать формулы обращений, уметь выражать благодарность, просьбу, согласие, возражение и др.). Предложенные упражнения могут быть использованы при проведении ролевых игр для русского и других языков, изучаемых как иностранные, направленных на развитие профессионально-коммуникативных качеств специалистов сферы туризма.

Ключевые слова: Ролевые игры, Методика преподавания русского языка, Педагогика, Речевой этикет, Коммуникация, Туризм

\section{Введение}

Между Турцией и Россией в секторе туризма развивается партнерство, являющееся прочным фундаментом сотрудничества двух стран. Согласно статистике Министерства культуры и туризма Турции, в 2019 году страну посетили 6,7 млн. российских туристов. Россия стала абсолютным лидером по турпотоку в Турции в 2019 году. В условиях глобализации экономики, всплеска в развитии туризма в Турции, с увеличением числа туристов из России, а также с учётом ужесточающейся с каждым годом конкуренции на рынке труда всё более актуальными становятся вопросы обучения русскому языку студентов специальности «Туризм». Высокий уровень речевой культуры и развитая экономика просто неотделимы друг от друга. Обучение иностранному языку как неотъемлемому компоненту профессиональной подготовки специалистов любого профиля должно носить коммуникативно-ориентированный и профессионально-направленный характер. В последние годы растет популярность игрового метода профессиональной подготовки специалистов различного уровня. Ролевые игры, как педагогическое явление, исследуются в научно-теоретической литературе авторами: Б.Т. Ананьевым, Э.Берном, Д.Б. Выготским, К.Гроссо, В.В.Давыдовым, А.Н.Леонтьевым, С.Л.Рубинштейном, А.С. Макаренко, К.Д.Ушинским, П.И.Пидкасистым, М.М.Бирштейном, А.А.Вербицким, Н.П. Аникеевой, П.Ф.Каптеревым, Л.Г.Денисовой, С.М.Мезениным, Е.К.Скляренко, Т.И. Олейник, А.А.Бадаевым, В.И.Рыбальской, И.Б.Первиным. Однако нам не удалось найти исследований, в которых бы рассматривались проблемы применения ролевых игр в формировании навыков речевого этикета русского языка в профессиональной подготовке специалистов сферы туризма.

\section{Цель Исследования}

Целью исследования является разработка ролевых игр, опирающихся на современные исследования в лингводидактики, культурологии и туризме, направленные на формирование 
навыков речевого этикета (русского языка как иностранного) РКИ в коммуникативной компетенции .

\section{Концепции и Методы}

В речевом взаимодействии коммуникантов одну из важных регулятивных функций выполняет микросистема языка, называемая речевым этикетом (Сичан, 2001:174). Речевой этикет любого языка отражает национально-культурную специфику общения данной страны, так как он связан с принятыми в ней правилами невербального поведения, обычаями и привычками носителей языка. Речевой этикет предписывает говорящим использование определенных формул в зависимости от ситуации общения. Носители языка интуитивно осуществляют выбор требуемых речевых единиц, ориентируясь на экстралингвистические условия, среди которых особое значение имеет степень официальности обстановки и отношений между говорящими. Успешное межкультурное взаимодействие базируется на ряде правил, сформулированных и охарактеризованных М.Я. Блохом: 1) внятность речи, 2) понятность речи, 3) вежливость (поведенческая уместность) речи, 4) стилеуместность речи, $5)$ кооперативный вызов на нужную реакцию, 6) переакцентуация лиц (в центре внимания слушающий), 7) оптимальная протяженность речи, 8) разумность (логичность), 9) интерес для слушающего, 10) кооперативное паралингвальное поведение (Блох, 2004: 3-7). Таким образом необходимо создавать условия для усвоения норм речевого этикета русского языка, что позволит им более уверенно чувствовать себя, определять стратегии и тактики речевого поведения и соответственно, выстраивать высококвалифицированную профессиональную речь.

В изучении русского языка как иностранного в коммуникативной подготовке студентов специальности «Туризм» целесообразно знакомить с теми речевыми средствами, которые в наибольшей степени способствуют решению их коммуникативных задач в повседневной жизни, поэтому обучение необходимо начинать с усвоения формул, применяемых в основных ситуациях повседневного общения. Ситуация ролевого общения может лишь тогда явиться стимулом развития спонтанной творческой речи, если она будет динамичной, а не статичной, связанной с решением определённых проблем и коммуникативных задач. Участники игры должны быть поставлены в такие условия, при которых необходимо выяснить социальные, эмоциональные и познавательные стороны межличностных отношений. В процессе работы с моделями русского речевого этикета должно происходить активное соединение умений студентов с социокультурной реальностью изучаемого языка при непосредственном участии преподавателя, использовании учебников и других средств обучения. На сегодняшний день в методике преподавания русского языка как иностранного представлено большое разнообразие способов формирования у студентов навыков речевого этикета. К ним относятся ознакомление с основными особенностями русского коммуникативного поведения, трансформационные, подстановочные, вопросно-ответные типы упражнений, задания с дефинициями, работа с оригинальными и адаптированными текстами, анализ особенностей употребления формул речевого этикета в конкретных ситуациях, ролевые и дидактические игры (Бердичевский, 2011:184).

Ролевая игра является одним из средств обучения культуре страны изучаемого языка. Такие слова, как ролевая игра, моделирование и драма иногда используются как синонимы, но, по сути, они иллюстрируют разные понятия. Моделирование - это ситуация, в которой студенты играют естественную роль, другими словами, роль происходит в реальной жизни (например, покупка продуктов или бронирование отеля) (Митрофанова, 1990:7). Н.П. Аникеева (2002) предлагает следующую классификацию игр: 
1. игры-драматизации, основанные на исполнении какого-либо сюжета, сценарий которого не является жестким каноном;

2. игры-импровизации, где действующие лица знают основной сюжетный стержень игры, характер своей роли, а сама игра развивается в виде импровизации;

3. игры на преодоление этапов, когда определяются этапы, на каждом из которых выполняется определенная задача познавательного характера;

4. деловые игры, в которых разыгрываются ситуации, построенные на выявлении функциональных связей и взаимоотношений между разными уровнями управления и организации.

Исследователь А.П. Панфилова (2009) предлагает свою классификацию интерактивных методов обучения:

1.Радикальные - стремление перестроить учебный процесс на основе использования компьютерных технологий (дистанционное обучение, виртуальные семинары, конференции, игры и пр.).

2.Комбинаторные - соединение ранее известных элементов (лекция-диалог и т.д).

3.Модифицирующие (совершенствующие) - улучшение, дополнение имеющейся методики обучения без существенного ее изменения (например, деловая игра).

Для создания реальных и воображаемых ситуаций общения в образовательном процессе применяем различные интерактивные методы (ролевые игры, дискуссии, творческие проекты и др.). На занятиях русского языка в обучении студентов специальности «Туризм» обыгрываются ситуации в сфере туризма. В основу ролевых игр могут быть положены простые ситуации: экскурсия по историческим местам, план туроператора,поход в музеи и т.д. Например, можно организовать ролевую игру «В турагентстве», где один студент исполняет роль туристического агента , а другой - клиента; «В ресторане отеля», где один студент играет роль посетителя, а другой официанта отеля; «В аэропорту (покупаем билеты)» ; УУ стойки регистрации в отеле» и т.д. Как пишет О. С. Тарасенко (2006), «подобные занятия могут проводиться при изучении любых грамматических тем, для контроля усвоения лексического и грамматического материала». Использование ролевых игр помогает создать на уроке положительный микроклимат, организовать целенаправленную речевую практику на русском языке, тренировку и активизацию в ее рамках навыков и умений монологической и диалогической речи, также осуществить индивидуальный подход к обучению, что позволяет реализовывать принцип успешности для каждого студента и повышает мотивацию к изучению русского языка. Однако, несмотря на достаточно большое количество форм, методов и приемов работы по обучению иноязычных студентов речевому этикету, применять их можно не на всех этапах обучения языку. Большинство из существующих на сегодняшний день пособий по формированию речевых этикетных навыков рассчитаны на студентов, у которых уровень владения языком выше базового. Упражнения в них основаны на сложном языковом материале, а в качестве текстового материала используются фрагменты из произведений художественной литературы, лексика и грамматика, которые не актуальны для иностранцев, и к тому же сложна для восприятия. Тем не менее вопрос правильного употребления в речи основных речевых этикетных средств является для них актуальным, поскольку знание базовых формул речевого этикета позволит им грамотно осуществлять элементарные речевые действия в повседневных бытовых ситуациях общения. Включение в образовательный процесс дидактической игры как средства развития речевого этикета (форма организации обучения и контроля коллективной учебной деятельности, включающая комплекс ситуаций речевого общения, объединенных единым сценарием, который учит речевому поведению, 
вырабатывает умение учитывать различные обстоятельства общения) (Мишанова, 2007: 6). В данной статье представлены некоторые варианты ролевых игр, которые включены в комплекс упражнений по формированию навыков речевого этикета, разработанного для турецких студентов, владеющих русским языком от базового до продвинутого уровня РКИ. Предложенные задания включают упражнения разного уровня сложности: от упражнений репродуктивного характера до заданий коммуникативной, направленности, в которых обучающимся необходимо использовать изученные формулы в учебной коммуникации в ситуациях, максимально приближенных к реальным. Обязательным условием выполнения упражнений и развития речи является наличие коммуникативной установки: выражение согласия/несогласия, обращение с просьбой или вопросом, советом или предложением, уточнение, пояснение, дополнение, опровержение, выражение благодарности или недовольства и т.д.(Филатчева, 2012:15). В первом упражнении предлагаются задания репродуктивного характера: соотнесение картинки.

\section{Задание 1.}

1) Опишите следующие иллюстрации:

На доске иллюстрации; задание заключается в том, чтобы подобрать к ним соответствующие формулы речевого этикета. При изучении темы «Встреча туристов», «Гостиница», предлагаются картинки с изображением данных тем и список следующих фраз: «Рад вас видеть!», «Приглашаем к столу!», «Счастливого пути!», «Добро пожаловать!», «Будь здоров!», «С днем рождения! », «Спокойной ночи!», «С Новым годом!».

2) Студенты обсуждают иллюстрации и преподаватель распределяет роли (одушевленные и неодушевленные): гостиница, турецкая баня, турист из России, ресторан, гид и т.д. (К примеру: «Добрый день! Разрешите представиться: я гостиница. Меня зовут Марко Поло. У меня 1200 комнат. Они удобные, светлые и с видом на море. Хочу поделиться с вами - я не люблю своего директора, потому что он злой»).

Данный тип задания формирует умение применять изученные формулы речевого этикета и исходя из предложенной ситуации, выбирать из существующих речеэтикетных средств те, которые наиболее уместны в конкретной ситуации общения. Овладение национально-специфическими устойчивыми формулами общения необходимо не только для адекватного общения и взаимопонимания в межнациональной коммуникации, но и для получения представления о национально-культурных особенностях (менталитете) народаносителя языка (Жидкова, 2013:61).

\section{Задание 2.}

Формулы приветствия и прощания:

1) Посмотреть видео (два диалога):

а) -Здравствуйте! Есть ли у вас свободный двухместный номер?

- Сегодня вообще нет свободных мест.

- А завтра?

- Нет.

- Жаль.

б) -Алло. Здравствуйте. Будьте добры, позовите пожалуйста, Эсру.

- Сейчас.

- Алло. Я слушаю. 
- Эсра, ты сегодня не была на работе. Как ты себя чувствуешь?

- Я заболела. Спасибо. Сейчас мне уже лучше.

- Мы бы хотели тебя навестить. Когда это можно сделать?

- Очень рада, но доктор пока не разрешает.

- Выздоравливай. До свидания. диалогов.

2) Проанализировать просмотренные диалоги и предложить свои варианты данных

3) Проанализируйте следующую ситуацию и скажите, в чем проявляется нарушение норм речевого этикета.

У Петра была назначена деловая встреча в кафе. Представителя фирмы, с которой сотрудничала его компания, он не знал, поэтому встретившись с ним в кафе, сказал:«Добрыйдень! Меня зовут Боран. Я представитель компании «Джолли-тур». Но собеседник сказал: «Приступим к делу».

Студентам предлагаются задания, где им необходимо сформулировать предложение, используя наиболее уместную для данной ситуации общения формулу речевого этикета. В качестве примера можно привести следующее задание тематической группы: поздравление, пожелание, приглашение.

\section{Задание 3.}

Сформулируйте высказывание, используя наиболее уместную формулу пожелания, поздравления или приглашения:

- У туриста медовый месяц. Поздравьте его с этим событием.

- Сегодня день рождения у коллеги. Произнесите поздравительный тост.

-У вас через неделю в отеле вечер Русской музыки. Пригласите на торжество туристов.

- Пригласите на экскурсию новоприбывших туристов.

-Ваша группа туристов собирается на экскурсию с другой туристической компанией. Поинтересуйтесь подробностями и пожелайте им удачи.

- После тура попрощайтесь со своей группой туристов.

Данный тип задания формирует умение специалистов по туризму правильно оценить поступающую информацию с тем, чтобы выработать свою собственную стратегию вербального и невербального поведения.

\section{Задание 4.}

Составьте диалоги по предложенному сценарию: магазины,

1)Туристам посоветуйте достопримечательности, которые можно посмотреть;

где можно купить хорошие вещи и сувениры; другие интересные места.

2) Посоветуйте туристам экскурсионные туры.

3) Вы хотите обменять деньги. Узнайте, где находится банк.

\section{Задание 5.}

1) Позвоните директору и расскажите о проблеме туриста. 
2) Позвоните в «Turkish Airlines» и забронируйте билет на самолет.

3) Позвоните в ресторан и закажите пиццу.

4) Позвоните в отель и забронируйте два люкс номера. отдых.

5) Позвоните в туристическую компанию и поблагодарите руководство за хороший

6) Позвоните на ресепшен отеля и попросите поменять на номер с видом на море.

7) Позвоните в отдел бронирования и пожалуйтесь на свои проблемы.

8) Позвоните в аэропорт и узнайте о причине задержки рейса.

9) Позвоните менеджеру и сообщите о проблеме низкокачественного обслуживании персонала в номере.

Данное задание заключается в отработке конструкций для ведения телефонного разговора, что вырабатывает умение выбирать и использовать подходящие для рассматриваемой ситуации коммуникативные тактики, необходимые для создания толерантного пространства.

Задание 6.

Раздаются карточки по количеству студентов в группе с описанием разных проблем. Каждый студент дает совет, как эту проблему решить. Студенты должны использовать разные конструкции выражения совета.

- Хочу в пятницу пригласить тебя на экскурсию в Софийский собор.

- Извини, но я не могу.

- Но ты же хотел еще раз посетить этот музей.

- Да, но в пятницу у меня тренировка.

- В музей можно сходить до 16.00 , а на тренировку можно сходить вечером.

- Я в принципе уже был в этом музее.

- Если честно, мне билеты в музей оплатил университет.

- Ничего страшного, пригласи кого-нибудь другого.

- Я хотел сделать тебе сюрприз.

Задание 7.

Составьте диалоги по предложенному сценарию:

1) Вы работаете аниматором в отеле.У вас работа интересная, но зарплата низкая. Вам нужно повысить зарплату.

2) Ваш повар готовит еду с приправами. Но вашим клиентам не нравятся приправы. Из-за этого у вас постоянно возникает конфликт с туристами.

3) Вы отдыхаете в чужой стране и вас просят рассказать о своем родном городе.

4) Вы решили отправиться в путешествие, но не можете сделать выбор.

5) Вы сотрудник отдела бронирования, опишите услуги отеля.

Данный тип задания формирует умение соотносить языковые средства с нормами речевого поведения носителей русского языка; уметь вступать в коммуникацию и строить 
монологические и диалогические высказывания адекватно целям и сферам общения. Разыгрывание ролей представляет собой определенный вид деятельности, направленный на активизацию личности. Каждый участник является носителем определенного вымышленного образа роли, который он демонстрирует перед другими участниками и вживается в эту роль. Для осуществления «театральной деятельности» необходимо создать среду естественной коммуникации с условиями осуществления образовательного процесса. (Якуп Акйел, 2013:170). Таким образом, необходимо разрабатывать и использовать в каждодневной работе коммуникативные упражнения, которые дадут возможность создавать ситуации речевого общения, то есть языковую среду (Аманулла, 2007:40). К примеру, на занятии вы можете применить метод интерактивного обучения - пресс-конференцию туроператоров из разных стран, описанную в задании 8.

\section{Задание 8.}

На подготовительном этапе разрабатывается сценарий, план, общее описание игры и распределение ролей участников из разных стран, переводчиков русского языка, модератора и приглашенных высокопоставленных чиновников (министр туризма и т.д.). Студенты должны заранее подготовиться к материалу с презентацией, оформить столы своих турагентств: плакаты, буклеты, брошюры. Обязательное наличие вывески с названием вымышленного агентства, бейджи с именами и т.д. В основе разыгрывания ролей лежит заранее подготовленная ситуация пресс-конференции. Необходимо каждому студенту представить свою презентацию доклада длительностью 5-10 минут и разыграть еe в лицах. При подготовке и проведении данной пресс-конференции туроператоров, студенты применяют усвоенные знания в условиях, имитирующих реальную социальную и профессиональную практику взаимодействия с представителями иных культур, осваивают опыт эффективного межкультурного взаимодействия и воссоздают акт естественной коммуникации, изображая вымышленных персонажей. После завершения имитационной конференции эксперты осуществляют экспертизу всей деятельности участников игры и готовят отчет по анализу идей. Эта вымышленная пресс-конференция представляет собой условное воспроизведение ее участниками практической деятельности людей, создавая тем самым условия для реальной коммуникации. На этом занятии в условиях коллективной работы студенты приобретают не только навыки говорения русского языка, но и ценностные ориентации и навыки социального взаимодействия, присущие будущему специалисту туристической сферы. Преимуществом данной игры является то, что она достаточно мобильна, легко адаптируется и модифицируется для разных сфер как туризм, коммуникация и для специалистов любого профиля. Для этого достаточно лишь разработать соответствующую модель ролевой игры и ситуации в рамках конкретной профессиональной деятельности.

\section{Задание 9.}

Все студенты группы делятся на пары, в каждой из которых есть роли туриста иностранца, переводчика и рассаживаются в аудитории в расстановке посадочных мест автобуса. Роль гида постоянно меняется. С двух сторон развешиваются иллюстрации достопримечательностей. При этом каждый из студентов подготовил свое коммуникативное задание по информации. об историческом или культурном объекте. Экскурсовод приступает к экскурсионному туру по городу и в процессе туристы на русском языке задают максимально точный вопрос или дают максимально точный ответ, используя изученный лексикограмматический материал. Некоторые туристы, прибывшие на экскурсию со своим переводчиком английского или турецкого языков задают вопросы экскурсоводу, при этом не только отрабатываются навыки синхронного перевода и построения собственного высказывания, но и формируется способность вступать в коммуникацию и вести диалог. 
Выполнившие задачу в роли гида и туриста студенты выступают в роли наблюдателей и экспертов по оценке правильности выбора моделей речевого этикета, грамотности употребления конструкций с глаголами, точности задаваемых вопросов и полноты ответов, а также невербальному поведению участников ролевого общения. Каждый из участников диалога получает оценку эксперта по стобалльной шкале, которые записываются на доске. Преподаватель, осуществляя контроль усвоения знаний и формирования навыков, в конце игры дает поощрительные и штрафные баллы за фонетическое оформление диалогов, а также экспертам-за умение аргументировать оценку, выставленную по тому или иному критерию. В данной ролевой игре представлены задания, направленные на формирование умения определять уместность использования формул речевого этикета, ориентироваться в потоке профессиональной информации и усвоение специальной лексики и терминологии, определять коммуникативные намерения диалогического партнера, формировать опыт публичного выступления, инициировать и завершать диалог, выражать свое коммуникативное намерение в пределах изученных тем, адекватно реагировать на реплики собеседника. Эта ролевая игра применяется для студентов специальности «Туризм» на занятиях русского языка с целью отработки речевого этикета и формирования профессиональных умений. Как известно, знание русского языка является неотъемлемой частью подготовки высококвалифицированных специалистов в области туризма и гостеприимства в отелях Турции. Организация и проведение ролевых игр требует серьезной подготовки, включая использование системы управления отелем. На занятиях с преподавателем русского языка студенты повторяют и обобщают специфические особенности профессии, в рамках которой реализуется коммуникация, достигается понимание цели игры и содержания. В ходе игры приобретаются следующие навыки: логическое мышление, способность работать в команде, уверенность в себе, способность сконцентрироваться на сути проблемы.

\section{Задание 10.}

Интервью у знаменитого актера или певца.

Содержание игры: у всемирно известных звезд проводится интервью. Задача студентов организовать интересное, культурно-развлекательное шоу, учитывающее интересы различных слоев населения, а не только поклонников. Студенты получив роли, самостоятельно согласовывают следующие ответы: кто играет на каком инструменте; сколько альбомов выпустили, особенности каждой из историй; какие из стран посетили; дают комментарии по поводу одного из скандалов в СМИ, задача которых представить в лучшем свете и задают разнообразные вопросы. Студенты максимально творчески подходят к выполнению заданий и создается атмосфера сотрудничества, дружелюбия и уважения друг к другу.

Цель ролевой игры: отработка речевых умений говорения и аудирования по тематике культуры, искусства и развлечений. Задачи ролевой игры заключаются в реализации студентами подготовленной и неподготовленной диалогической и монологической речи. Отрабатываемые в процессе игры средства формирования речевых умений говорения:

- монолог-размышление (о перспективах развития культуры и т.д.)

-монолог-описание (образа жизни людей различных социальных, профессиональных и возрастных групп и т.д. в современном мире и в различные исторические периоды; произведений искусства; культурных мероприятий; природных ландшафтов и т.д.)

-монолог-сообщение (о выдающихся личностях, открытиях, событиях, о деятельности в различных сферах социально-экономической и культурной жизни) 
-монолог-размышление (о перспективах развития отрасли / языков / культур и т.д.) диалог- расспрос (об особенностях жизни и деятельности представителей различных культур/организаций/групп; о предоставляемых услугах и т.д.)

- диалог-убеждение/побуждение к действию.

В работе со студентами, владеющих русским языком на продвинутом уровне РКИ, игровая ситуация может быть воссоздана посредством описаний, текстов художественных произведений и других материалов, используемых в качестве устноречевых опор. Ролевые игры на занятиях по русскому языку могут быть построены на базе, к примеру, художественного произведения Артура Хейли «Аэропорт», в котором раскрывается закулисье аэропортов, самолетов и бинарный конец, когда сами студенты решают как закончить произведение. Роман Д.Томаса «Белый отель», Бунина «Господин из СанФранциско», Стивена Кинга «Сияние», сюжеты которых происходят на территории отеля, профессионально значимы для обучающихся. На основе всего художественного произведения или его фрагментов можно создать «искусственные» ситуации, которые сделают студентов «соучастниками» действия (эпизодов, событий) и тем самым вовлекут их в проблемы и конфликты персонажей. Ролевые игры дают возможность обучающимся стать «соавторами» произведения, «вмешаться» в действия и поступки персонажей, попытаться изменить ход событий. Студенты создают новые ситуации, которые не были описаны автором, сами становятся «авторами» нового произведения, решая новые проблемы и сталкиваясь с новыми конфликтами. В играх студенты ведут разговоры, обсуждают, действуют от лица персонажей и автора, решают проблемы персонажей, дают им советы, критикуют или хвалят героев. Персонажи могут слушать советы или не обращать на них внимания, спорить или соглашаться, радоваться или огорчаться и т.д. Таким образом, герои из другой действительности и другого времени могут стать для студентов собеседниками, друзьями, врагами, партнерами и т.д. Студент в учебном процессе должен выполнять «роль не слушателя, а быть ключевой фигурой в нем» и выражать свою точку зрения, вести дискуссии, принимать правильные решения. (Каримова, 2017: 336 ). Ролевую игру можно воссоздать не только на базе художественного текста, но посредством видеоматериалов, базирующихся на одном из старейших и основном принципе наглядности. Перед показом необходимо отработать языковые средства с нормами речевого русского этикета, построить монологические и диалогические высказывания и в ходе показа видеоматериала с опорой на материалы пособий (фрагменты адаптированных текстов) студенты знакомятся с особенностями профессиональной деятельности гидов; персонала гостиничного дела; таким образом они получают первое представление о своей будущей профессии. Главная причина - незнакомые средства речевого этикета, звучащие в фильме. Для эффективного использования видеоматериала необходимо этикетные формулы показать до просмотра фильма на экран посредством презентации с иллюстрациями, например, развлечения в отеле, пословицы, используемые в кадре, правила и обязанности персонала и т.д. Такая работа поможет студенту понять лексику видеоматериала, который последует после подготовительной работы. При организации уроков c демонстрацией видеоматериала необходимо помнить, что структурно должны быть задействованы все аспекты обучения: лексика и грамматика, говорение, письмо, чтение и говорение (ролевая игра и контроль). После просмотра студентам предстоит выполнить тест на понимание фрагмента, ответить на проблемные вопросы. Все задания должны быть направлены на формирование речевых навыков. Для закрепления этого материала необходимо интегрировать (в данном образовательном «поле») несколько интерактивных методов обучения,построенной на основной теме видеоматериала. Преподавателем разрабатывается ролевая игра «Профориентация», позволяющая привязать изучаемый материал к формированию навыков речевого этикета в данной речевой ситуации. 
Видеоматериал продемонстрировал вид деятельности специалистов туристического сектора, студенты могут подготовить и инсценировать данную ролевую игру. Перед ними ставится следующая задача: каждый из вас мастер своего дела (ресторатор, гид, менеджер отеля, бариста ( или специалист по приготовлению кофе)), директор спортклуба, официант, повар и т.д. Студентам предстоит рассказать о достоинствах профессий на русском языке, используя профессиональную лексику видеоматериала. Студент оказывается свободным в выборе языковых средств, которыми он уже овладел. Тем не менее, его речевое поведение уже предопределено в видеоматериале, поскольку их соблюдение входит в правила игры. Мы полагаем, что выбор роли -один из важнейших аспектов ролевой игры, поскольку он связан со степенью самостоятельности студента при подборе языковых и речевых средств и сформированности умения самопрезентации в определенной ситуации. Развлечение не является целью ролевой игры, но в то же время она не должна быть скучной. Возможность представить себя в роли, которая для студента неординарна, интересна, неприемлема в обычной жизни, связана с риском, требует особых способностей и т.д. Понимание и принятие роли своей будущей профессии предполагает наличие знаний по специальности, а также оперирование профессионально значимыми решениями. Данная игра способствует накоплению умений и навыков работы в коллективе, помогает оценить новые социальные отношения в органической связи с этикой профессиональной деятельности,расширяет личностные возможности студентов, дает ощущение уверенности в себе.

Для студентов, владеющих русским языком на продвинутом уровне, доступным видом заданий становятся интерактивные командные игры, такие как «Аукцион отелей », «Клуб путешественников», «Экспедиции», « Международные научные конференции», «Продажа туров».Такого рода интерактивные методы обучения позволяют студентам расширить свои знания о стране, язык который ими изучается, а также информацию о культурно-исторических достопримечательностях родного края и вместе с этим проверить общий уровень знаний, эрудицию, логику. Тему «Путешествие по городам России и Турции» на занятиях русского языка начального уровня можно провести при помощи карт России и Турции. Студенты отображают схему «Моя дорога домой» на картах при помощи значков: «самолёт», «поезд», «автобус», «автомобиль», «корабль». Они должны, где нужно подсчитать время пути на всех отрезках с учетом остановки, пересадки и организовать ситуацию, которая стимулирует их умственную деятельность, заставляя их быстрее выражать свои мысли на русском языке. Наиболее популярными заданиями, представляемыми на занятиях по русскому языку являются приготовления по рецепту блюд зарубежной кухни, информационный проект «Жизнь замечательных людей», проведение обзора первой страницы газеты на изучаемом языке, организация концерта или постановки пьесы, составление брошюры для туристов, переписка по электронной почте (Ахметова, 2019:18).

\section{Заключение}

Системное выполнение данных заданий способствует достижению главной цели обучения - получение навыков речевого этикета в коммуникативной подготовке студентов специальности «Туризм», способности осуществлять речевую деятельность в соответствии с ситуацией общения, используя наиболее уместные формулы и клише, что будет способствовать их адаптации в русскоязычной среде. Результаты исследования подтверждают целесообразность и эффективность применения различных ролевых игр, способствующих повышению качества обучения и интереса к изучению предмета, обучают естественной коммуникации, позволяют активизировать студентов в процессе освоения русского языка, побуждают их к совершенствованию своих коммуникативных умений, 
расширению и углублению профессиональных знаний, которые открывают будущему специалисту перспективы личностного и карьерного роста в сфере туризма.

Подводя итоги исследовательской работы, предлагаем ряд выводов и предложений:

В индустриальную эпоху инновационных технологий необходим постоянный поиск новых интегрированных принципов и интерактивных методов обучения, для того чтобы сформировать стойкую положительную мотивацию студентов в отношении русского как иностранного языка и добиться наиболее оптимального уровня в усвоении учебного материала .

Освоение русского языка невозможно без навыков живого общения, но, к сожалению, довольно часто с этим возникают сильные затруднения ввиду невозможности устроить открытый урок с носителями языка. В связи с этим целесообразным представляется организовать на уроках русского языка круглые столы, дискуссии и ролевые игры, посвященные изучаемым проблемам, чтобы помочь студентам включиться в активное общение, научиться правильно и грамотно излагать свои мысли с нормами речевого этикета русского языка. Мы выяснили, что применение интерактивного метода ролевой игры способствует не только повышению интереса к изучению языка, но и создают иллюзию участия в реальной жизни страны изучаемого языка, а это в свою очередь, обеспечивает представление о культуре, законах и поведении русского народа.

Чтобы улучшить свое знание русского языка, расширить свой культурологический минимум и, может быть, ощутить себя частью русского культурологического пространства необходимо расширить международное сотрудничество в области студенческих обменов с университетами России (летняя стажировка в отелях на 3 месяца) и разработать образовательные программы. Во время таких стажировок студенты познакомятся с правилами этикета коммуникации на русском языке, что позволит расширить их собственный репертуар этикетных формул. (Коваль, 2014:51).

С городскими местными музеями разработать и внедрить в практику музейнообразовательные программы (самостоятельная работа студента, выполненная на архивном материале). В учебную программу включив экскурсии по городу и городским музеям (рабочий язык-русский язык), студенты получат первичные профессиональные умения и навыки.

\section{Литература}

Аманулла 3. (2007). Трудности обучения аудированию русской речи китайских студентов и пути их преодоления. Русский язык за рубежом, №5. 39-44

Аникеева Н.П. (2002). Воспитание игрой.М.Знание. 204

Ахметова Н.А. и другие (2019). Формирование профессиональной компетентности студентов интерактивными методами обучения на занятиях практического курса русского языка // Вестник Оренбургского государственного университета. - 2019. -№2(220). - С. 1520. https://doi.org/10.25198/1814-6457-220-15

Бердичевский А.Л.(2011) . Методика межкультурного образования средствали русского языка как иностранного , М. : Русский язык. Курсы. 184

Блох М.Я. (2004). Прагматика, этика и эстетика языкового общения. Лингвистика и лингвистическое образование в современном мире.М. : ГНО «Прометей» МПГУ.3-7. 
Жидкова Ю.Б. Речевая адаптация в лингвострановедческом аспекте на начальном этапе обучения русскому языку иностранцев, Лингвистика и межкультурная коммуникация Выпуск №9

Каримова Б. и другие (2018) Синергетический подход в трехъязычном образовании Республики Казахстан Synergetic approach in trilingua education of the Republic of Kazakhstan Revista de Ciencias Humanas y Sociales, Opción, Año 34, № 85, Maracaibo Venezuela, Universidad del Zulia Venezuela, 327-343. http://www.scopus.com/inward/record.url?eid=2-s2.085050943285\&partnerID=MN8TOARS

Коваль П.Е. и другие (2014). Деловой человек пишет по-русски: культура письменной речи делового человека: составляем отчет, доклад, деловое письмо. Хроники объединенного фонда электронных ресурсов Наука и образование., №11 (66): 50.

Митрофанова О.Д. (1990). Методика преподавания русского как иностранного.М: Русский язык

Мишанова О.Г. (2007). Педагогические средства развития речевого этикета младших школьников в курсе «Окружающий мир» Екатеринбург : Челябинский Государственный Педагогический Университет, 16.

Панфилова А.П. (2009). Инновационные педагогические технологии: Активное обучение учеб. пособие для студ. высш. учеб. заведений $\mathrm{M}$ : Издательский центр «Академия»,192.

Сичан Л. (2001). Русский речевой этикет в прагматическом и лингвострановедческом аспектах с точки зрения носителя китайского языка: дис. канд. филол. наук. М. 174 .

Тарасенко О. С.(2016). Организация интерактивного обучения в юридических вузах. Актуальные проблемы методики преподавания русского языка как иностранного: материалы II междунар. науч.-практ. конф. Уфа

Филатчева ММ. (2012). Формирование речевых навыков у студентов неязыковых вузов. Актуальные проблемы преподавания иностранных языков в неязыковых вузах (материалы Межфакультетской научно-методической конференции) Под науч. редакцией: Т. В. Соколова М.: Издательский дом НИУ ВШЭ

Якуп Акйел и Нихат Чалышкан. (2013). Оценка компетенций драматического метода учителей, работающих в дошкольных образовательных учреждениях. Yakup Akyel ve Nihat Çalışkan (2013) Okul Öncesi Eğitim Kurumlarında Görev Yapan Öğretmenlerin Drama Yöntemi Yeterliliklerinin Değerlendirilmesi. Ahi Evran Üniversitesi Kırşehir Eğitim Fakültesi Dergisi (KEFAD) Cilt 14(3), 161-173. 